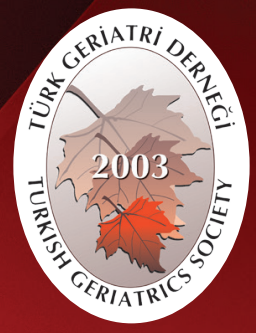

Turkish Journal of Geriatrics

DOI: 10.31086/tjgeri.2018239388

2018;21 (2):134-142

- Oya ÖZDEMiR ${ }^{1}$

- Pınar BORMAN ${ }^{1}$

- Ayşegül YAMAN

\title{
UPPER EXTREMITY FUNCTION IN ELDERLY PATIENTS WITH BREAST CANCER-RELATED LYMPHEDEMA: A DESCRIPTIVE STUDY
}

\section{Abstract}

Introduction: Lymphedema is a common complication following breast cancer treatment with physical and pyschosocial consequences. The detrimental effects of lymphedema may become more disabiling in conjuction with the aging process. The aim of the study was to evaluate upper extremity function in elderly with breast cancer-related lymphedema and investigate the associations between upper limb function and demographic/clinical characteristics.

Materials and Method: Eight-four women with a mean age of $65.1 \pm 5.0$ years were enrolled in this study. Demograpic characteristics including age, body mass index, dominant hand, marital status, education level, and occupation were recorded. Cancer and lymphedemarelated clinical features were reviewed. The disabilities of arm, shoulder, and hand (DASH) questionnaire was used to assess upper extremity function.

Results: The mean of patients' body mass index was $31.9 \pm 6.1 \mathrm{~kg} / \mathrm{cm}^{2}$. The median duration of lymphedema was 8 months. Approximately $60 \%$ of patients had stage 2 lymphedema. The median value of interlimb volume difference was $558.5 \mathrm{ml}$. DASH score correlated only with body mass index, volume difference, and lymphedema stage. On regression analysis, the best predictors of upper extremity function in patients with lymphedema were found to be as body mass index and volume difference.

Conclusion: The presence of breast cancer-related lymphedema negatively affects upper extremity function in elderly patients. The findings indicate that patients with higher body mass index and interlimb volume difference have more severe disability. Therefore, multimodal therapeutic interventions for reducing volume of the affected arm as well as body mass index could improve upper extremity function in older patients with lymphedema.

Keywords: Breast neoplasms; Lymphedema; Aged; Upper extremity

\section{ARAŞTIRMA}

CORRESPONDANCE

\section{Oya ÖZDEMIR}

Hacettepe University, Faculty of Medicine,

Department of Physical Medicine and

Rehabilitation, Ankara, Turkey

Phone: 03123094142

e-mail: oyaunalozdemir@yahoo.com

Received: 27/03/2018

Accepted: 18/04/2018

Hacettepe University, Faculty of Medicine, Department of Physical Medicine and Rehabilitation, Ankara, Turkey

\section{MEME KANSERI ILE ILIŞKILI LENFÖDEMi OLAN YAŞLI HASTALARDA ÜST EKSTREMITE FONKSIYONU: TANIMLAYICI BİR ÇALIŞMA}

\section{Öz}

Giriş: Lenfödem, meme kanseri sonrası sık görülen bir komplikasyon olup fiziksel ve psikososyal sonuçlara yol açmaktadır. Lenfödemin zararlı etkileri, yaşlanma süreci ile birlikte daha fazla disabilite gelişmesine neden olabilir. Bu çalışmanın amacı, meme kanseri ile ilişkili lenfödemi olan yaşlılarda üst ekstremite fonksiyonları değerlendirmek ve üst ekstremite fonksiyonu ile demografik/klinik özellikler arasındaki ilişkileri araştırmaktır.

Gereç ve Yöntem: Çalışmaya ortalama yaşları $65.1 \pm 5.0$ yıl olan 84 kadın katıldı. Yaş, vücut kitle indeksi, dominant el, medeni hal, eğitim düzeyi ve meslekten oluşan demografik özellikler kaydedildi. Kanser ve lenfödem ile ilişkili klinik özellikler gözden geçirildi. Üst ekstremite fonksiyonunu değerlendirmek amacıyla Kol, Omuz ve El Sorunları (DASH) anketi kullanıldı.

Bulgular: Hastaların ortalama vücut kitle indeksi $31.9 \pm 6.1 \mathrm{~kg} / \mathrm{cm}^{2}$ idi. Lenfödem süresinin medyan değeri 8 aydı. Hastaların yaklaşık \%60'ı evre 2 lenfödeme sahipti. İki ekstremite arası hacim farkının medyan değeri $558.5 \mathrm{ml}$ idi. DASH skoru ile sadece vücut kitle indeksi, hacim farkı ve lenfödem arasında korelasyon mevcuttu. Regresyon analizi sonucunda, lenfödemi olan hastalarda üst ekstremite fonksiyonunu en iyi tahmin eden değişkenlerin vücut kitle indeksi ve hacim farkı olduğu belirlendi.

Sonuç: Yaşlı hastalarda meme kanseri ile ilişkili lenfödemin varlığı üst ekstremite fonksiyonlarını olumsuz etkilemektedir. Bu çalışmanın bulguları, daha yüksek vücut kitle indeksi ve ekstremiteler arası hacim farkı olan hastaların daha fazla disabiliteye sahip olduğu göstermektedir. Bu nedenle, etkilenen kol hacminin yanı sıra vücut kitle indeksinin de azaltılmasına yönelik multimodal terapötik girişimlerin, lenfödemi olan yaşı hastalarda üst ekstremite fonksiyonlarının düzeltebileceği düşünülmektedir.

Anahtar sözcükler: Meme kanseri; Lenfödem; Yaşıl; Üst ekstremite 


\section{INTRODUCTION}

Breast cancer is the most common type of malignancy among women worldwide. In recent years, early diagnosis and advanced treatments have significantly increased survival rates of these patients. Consequently, complications resulting from breast cancer treatment have also become more prevelant. Secondary lymphedema of the upper extremity is one of the most frequent and severe complications in breast cancer survivors, particularly among those undergoing radiotherapy following axillary lymph node dissection (1). Breast cancer-related lymphedema (BCRL) usually develops within the first 2 years after surgery and cases continue to slowly accumulate beyond this period. As reported in the literature, its incidence varies widely due to differences in terminology, study populations, methods of measurement, and timing of assessment. The average incidence of BCRL was found to be $21.4 \%$ in a systematic review including data from 30 prospective cohort studies published between 2000 and 2012 (2). As breast cancer typically occurs in women aged $>50$ years and survivors are now living longer, health care professionals specializing in geriatrics will more commonly encounter this disabling complication.

The initial symptoms of BCRL are tightness and feeling of heaviness in the affected limb. With the gradual increase in the volume of protein-rich fluid in the interstitium due to lymphatic obstruction, swelling becomes obvious and connective tissue fibrosis subsequently develops (1). In later stages, these changes may lead to functional impairment in the affected extremity contributing to limited activities of daily living and deteriorating quality of life (3-6). BCRL and its consequences may be more severe in elderly patients in conjuction with progressive reduction in physiological reserve due to the aging process and coexisting systemic diseases. Lymphedema could lead to functional limitations in elderly individuals, but knowledge regarding upper extremity function and its determinants in this population is lacking. Few studies have examined the relationship between age and upper limb function in patients with BCRL with conflicting results. While Park et al. reported that older patients with BCRL had worse upper limb function, the studies conducted by Pinto et al. and Smoot et al. found that patient age did not significantly affect upper extremity function $(4,5,7)$. Hence, the aim of this cross-sectional study was to evaluate upper limb function in elderly women with BCRL and examine the associations between arm function and demographic and clinical characteristics.

\section{MATERIALS AND METHOD}

Our study included a total of 84 women aged $\geq 60$ years with a diagnosis of BCRL who were consecutively admitted to our institution's lymphedema unit in the Department of Physical Medicine and Rehabilitation. Patients with bilateral breast cancer or lymphedema, any preexisting neurological or musculoskeletal disease affecting upper extremity function, or current upper extremity infection such as cellulitis or lymphangitis were excluded from the study. This retrospective study protocol was approved by the local ethics committee in accordance with the Declaration of Helsinki.

Demographic data, including patient age, body mass index (BMI), dominant hand, marital status, education level, and occupation were recorded. Clinical characteristics such as histological type and stage of breast cancer, surgical method, history of adjuvant treatment (chemotherapy, radiotherapy, and/or hormonotherapy), and comorbidities were extracted from the medical records. In addition, duration and side of lymphedema, volume difference between arms, stage of lymphedema according to International Society of Lymphedema Society (ISL) classification, pain severity (upper extremity, axilla, and breast) measured by $10-\mathrm{cm}$ visual analog scale (VAS), and limitations in shoulder joint motion were reviewed. Interlimb volume difference had been calculated by measuring the circumference of each upper extremity with a flexible tape measure, starting from wrist to axilla with $4 \mathrm{~cm}$ intervals 
and using the truncated cone formula, which was expressed both in milliliters $(\mathrm{ml})$ and percentages (\%). Further, disabilities of arm, shoulder, and hand (DASH) questionnaire score, which assessed upper extremity physical function, was recorded. The selfadministered DASH questionnaire consists of 30 core items with responses ranging from 0 to 5 . The scores are converted to 0 to 100 with higher scores indicating greater disability. The Turkish version of the DASH questionnaire has demonstrated excellent test-retest reliability and validity (8).

Statistical analyses were performed using IBM SPSS Statistics for Windows, version 22.0. Numerical variables were expressed as the mean \pm standard deviation or median and categorical variables as frequencies and percentages. Normality of continuous variables was evaluated by the Kolmogorov-Smirnov test, and homogeneity of variances was tested by the Levene test. Differences between groups according to DASH score were determined by independent samples $t$ test or one-way ANOVA, and the relationship between DASH score and other continuous variables was determined using the Pearson or Spearman correlation coefficient. Those variables with $p<0.25$ on univariate analysis were selected for the multivariate analysis. Factors affecting DASH score were determined by stepwise multiple linear regression analysis. A p-value of $<0.05$ was considered significant.

\section{RESULTS}

The mean age of the participants was $65.1 \pm 5.0$ years (range, 60-87). Of the 84 patients, 52 (61.9\%) were classified as obese $\left(\mathrm{BMl} \geq 30 \mathrm{~kg} / \mathrm{cm}^{2}\right)$, and the mean BMI was $31.9 \pm 6.1 \mathrm{~kg} / \mathrm{cm}^{2}$. Demographic charateristics of the patients are presented in Table 1. All patients underwent mastectomy for the treatment of breast cancer, with chemotherapy given to 70 patients, radiotherapy to 66 patients, and hormonoterapy to 60 patients. The most common histological type was invasive ductal carcinoma (85.7\%), and nearly two-third of participants had comorbidities, including hypertension, hyperlipidemia, diabetes mellitus, hypothyroidism, bronchial asthma, and congestive heart failure.

Overall, 80 patients were right-handed; the right side was affected in $48.8 \%$ of the patients, and lymphedema developed in the dominant extremity in 43 patients (51.2\%). While the duration of lymphedema varied widely from 1 month to 22 years, with a median value of 8 months, $60.7 \%$ of patients had lymphedema for $\leq 1$ year. The mean volume difference was $26.2 \% \pm 16.9 \%$ and ranged between $20 \%$ and $40 \%$ in most patients (52.4\%). The median volume difference in terms of $\mathrm{ml}$ was 558.5. Approximately $60 \%$ of patients had ISL stage 2 lymphedema. Fourteen patients (16.7\%) had pain in their arm and/or surgery scar (breast, axilla) with a mean VAS score of $4.1 \pm 1.8$ (range, 1-7). Furthermore, 12 patients (14.3\%) had limited shoulder motion. The mean DASH score was $41.0 \pm 23.8$. The clinical features of the participants are shown in Table 2.

Table 1. Demographic characteristics of the participants.

\begin{tabular}{lr}
\hline Age (years) (mean \pm sd) & $65.1 \pm 5.0$ \\
Body mass index (mean \pm sd) & $31.9 \pm 6.1$ \\
Dominant hand & \\
Right & $80(95.2 \%)$ \\
Left & $4(4.8 \%)$ \\
Marital status & \\
Married & $66(78.6 \%)$ \\
Single & $6(7.1 \%)$ \\
Widow & $12(14.3 \%)$ \\
Educational level & \\
Unlettered & $8(9.5 \%)$ \\
Primary & $30(35.7 \%)$ \\
Secondary & $3(3.6 \%)$ \\
High & $20(23.8 \%)$ \\
University & $23(27.4 \%)$ \\
Occupation & \\
Retired & $30(35.7 \%)$ \\
Housewife & $47(56.0 \%)$ \\
Officer & $7(8.3 \%)$ \\
\hline
\end{tabular}


Table 2. Clinical features of patients with BCRL.

\begin{tabular}{|c|c|}
\hline Characteristics & n (\%) \\
\hline $\begin{array}{l}\text { Histologic type } \\
\text { Invasive ductal } \\
\text { Invasive lobular } \\
\text { Invasive papillary } \\
\text { Mixed (ductal+lobular) }\end{array}$ & $\begin{array}{r}72(85.7 \%) \\
10(11.9 \%) \\
1(1.2 \%) \\
1(1.2 \%)\end{array}$ \\
\hline $\begin{array}{l}\text { Stage of breast cancer } \\
1 \\
2 \\
3 \\
\text { Unknown }\end{array}$ & $\begin{array}{r}6(7.1 \%) \\
51(60.7 \%) \\
24(28.6 \%) \\
3(3.6 \%)\end{array}$ \\
\hline $\begin{array}{l}\text { Surgery type } \\
\text { Simple mastectomy } \\
\text { Modified radical mastectomy } \\
\text { Radical mastectomy }\end{array}$ & $\begin{array}{r}14(16.7 \%) \\
67(79.8 \%) \\
3(3.6 \%)\end{array}$ \\
\hline $\begin{array}{l}\text { Chemotherapy } \\
\text { Yes } \\
\text { No }\end{array}$ & $\begin{array}{l}70(83.3 \%) \\
14(16.7 \%)\end{array}$ \\
\hline $\begin{array}{l}\text { Radiotherapy } \\
\text { Yes } \\
\text { No }\end{array}$ & $\begin{array}{l}66(78.6 \%) \\
18(21.4 \%)\end{array}$ \\
\hline $\begin{array}{l}\text { Hormonotherapy } \\
\text { Yes } \\
\text { No } \\
\text { Unknown }\end{array}$ & $\begin{array}{r}62(74.8 \%) \\
20(23.8 \%) \\
2(2.4 \%)\end{array}$ \\
\hline $\begin{array}{l}\text { Duration of lymphedema } \\
\leq 1 \text { year } \\
1-5 \text { years } \\
>5 \text { years }\end{array}$ & $\begin{array}{r}51(60.7 \%) \\
24(28.6 \%) \\
9(10.7 \%)\end{array}$ \\
\hline $\begin{array}{l}\text { Side of lymphedema } \\
\text { Right } \\
\text { Left }\end{array}$ & $\begin{array}{l}41 \text { (48.8\%) } \\
43 \text { (51.2\%) }\end{array}$ \\
\hline $\begin{array}{l}\text { Involvement of dominant side } \\
\text { Yes } \\
\text { No }\end{array}$ & $\begin{array}{l}43(51.2 \%) \\
41(48.8 \%)\end{array}$ \\
\hline $\begin{array}{l}\text { Volume difference } \\
<20 \% \\
20 \%-40 \% \\
>40 \%\end{array}$ & $\begin{array}{l}29(34.5 \%) \\
44(52.4 \%) \\
11(13.1 \%)\end{array}$ \\
\hline $\begin{array}{l}\text { Stage of lymphedema } \\
1 \\
2 \\
3\end{array}$ & $\begin{array}{r}32(38.1 \%) \\
50(59.5 \%) \\
2(2.4 \%)\end{array}$ \\
\hline $\begin{array}{l}\text { Pain } \\
\text { Yes } \\
\text { No }\end{array}$ & $\begin{array}{l}14(16.7 \%) \\
70(83.3 \%)\end{array}$ \\
\hline $\begin{array}{l}\text { Limitation in shoulder } \\
\text { Yes } \\
\text { No }\end{array}$ & $\begin{array}{l}12(14.3 \%) \\
72(85.7 \%)\end{array}$ \\
\hline $\begin{array}{l}\text { Comorbidities } \\
\text { Yes } \\
\text { No }\end{array}$ & $\begin{array}{l}54(64.3 \%) \\
30(35.7 \%)\end{array}$ \\
\hline
\end{tabular}


Table 3. Correlations between DASH score and demographic/clinical characteristics.

\begin{tabular}{|c|c|c|}
\hline & $\mathbf{r}$ & $p$ \\
\hline Age & 0.143 & 0.195 \\
\hline Body mass index & 0.365 & 0.001 \\
\hline Duration of lymphedema & 0.092 & 0.407 \\
\hline Volume difference (ml) & 0.277 & 0.012 \\
\hline \multirow[t]{2}{*}{ Volume difference (\%) } & 0.138 & 0.212 \\
\hline & Mean \pm sd & $p$ \\
\hline $\begin{array}{l}\text { Method of surgery } \\
\text { Radical mastectomy and MRM } \\
\text { Simple mastectomy }\end{array}$ & $\begin{array}{l}41.9 \pm 24.3 \\
36.2 \pm 21.7\end{array}$ & 0.417 \\
\hline $\begin{array}{l}\text { History of chemotherapy } \\
\text { Yes } \\
\text { No }\end{array}$ & $\begin{array}{l}41.1 \pm 24.4 \\
40.1 \pm 21.6\end{array}$ & 0.883 \\
\hline $\begin{array}{l}\text { History of radiotherapy } \\
\text { Yes } \\
\text { No }\end{array}$ & $\begin{array}{l}41.5 \pm 24.8 \\
39.1 \pm 20.6\end{array}$ & 0.718 \\
\hline $\begin{array}{l}\text { Side of lymphedema } \\
\text { Right } \\
\text { Left }\end{array}$ & $\begin{array}{l}41.5 \pm 23.4 \\
40.5 \pm 24.5\end{array}$ & 0.852 \\
\hline $\begin{array}{l}\text { Involvement of dominant side } \\
\text { Yes } \\
\text { No }\end{array}$ & $\begin{array}{l}41.4 \pm 23.0 \\
40.5 \pm 24.9\end{array}$ & 0.869 \\
\hline $\begin{array}{l}\text { Stage of lymphedema (ISL) } \\
1 \\
2 \text { and } 3\end{array}$ & $\begin{array}{l}34.5 \pm 24.8 \\
44.9 \pm 22.6\end{array}$ & 0.051 \\
\hline $\begin{array}{l}\text { Pain } \\
\text { Yes } \\
\text { No }\end{array}$ & $\begin{array}{l}48.9 \pm 25.6 \\
39.4 \pm 23.4\end{array}$ & 0.175 \\
\hline $\begin{array}{l}\text { Limited shoulder motion } \\
\text { Yes } \\
\text { No }\end{array}$ & $\begin{array}{l}48.9 \pm 28.6 \\
39.6 \pm 22.9\end{array}$ & 0.217 \\
\hline $\begin{array}{l}\text { Comorbidities } \\
\text { Yes } \\
\text { No }\end{array}$ & $\begin{array}{l}43.0 \pm 22.5 \\
37.4 \pm 26.0\end{array}$ & 0.304 \\
\hline
\end{tabular}

\begin{tabular}{lcccc}
\hline \multicolumn{4}{l}{ Table 4. Multivariate stepwise linear regression analysis results between DASH scores and correlation factors. } \\
\hline Correlation factors & B & sd & Beta & p \\
\hline Body mass index & 1.004 & 0.404 & 0.261 & 0.015 \\
Volume difference $(\mathrm{ml})$ & 0.015 & 0.005 & 0.325 & 0.003 \\
\hline
\end{tabular}


There were no statistically significant relationships between DASH score and patient age, surgical method, history of chemotherapy or radiotherapy, presence of comorbidities, duration of lymphedema, side of lymphedema, and whether dominant side was affected. Moreover, no significant differences in DASH scores were found between those with and without pain or limited shoulder motion. On the other hand, DASH score correlated with BMI, volume difference, and stage of lymphedema (Table 3). Accordingly, a stepwise multiple regression model was constructed using DASH score as a dependent variable and BMI, volume difference $(\mathrm{ml})$, stage of lymphedema, presence of pain, and limited shoulder motion as independent variables. Only BMI $(p=0.015)$ and interlimb volume difference $(p=0.003)$ significantly contributed to the variance in DASH score (Table 4). The combination of these two variables resulted in $R^{2}$ of 0.228 .

\section{DISCUSSION}

Breast cancer-related lymphedema has many physical and psychosocial ramifications, including physical discomfort, pain, limited arm movement, increased risk of infection, cosmetic disfigurement, anxiety, and depression (9). Following breast cancer treatment, survivors may have upper extremity impairments due to complications including pain and/or numbness in the shoulder, axilla, or lateral chest wall, limited shoulder motion, reduction in muscle strength, and lymphedema (10). Women with BCRL are reported to have a greater degree of upper limb disability than are those without lymphedema $(3,5,7,11)$. Reduced function of the lymphedematous arm corresponds with lower quality of life (6). The effects of lymphedema on physical function may be more profound in older versus younger patients, which in turn could decrease their ability to live independently (12). There are inconsistent findings in the literature regarding the relationship between patient age and upper extremity function. A study conducted by Park et al. divided 59 women with BCRL into three groups according to age (40-49, 50-59, and $\geq 60$ years) and found that the older the patient, the lower their upper extremity function (4). In contrast, Pinto et al. and Smoot et al. found no significant correlation between patient age and DASH scores $(5,7)$. To the best of our knowledge, few data exist regarding the effects of $B C R L$ on physical function in elderly patients $(9,12)$. For 7 years, Clough-Gorr et al. followed 400 women aged $\geq 65$ years who were diagnosed with primary stage I-IIIA breast cancer and found an overall prevalence of persistent lymphedema symptoms of $36 \%$, and presence of lymphedema had a noticeable negative impact on physical function measured by the Physical Function Index 10 (9). Another recent study with a 24-month follow-up evaluated 321 women aged $\geq 65$ years to determine the incidence of lymphedema and selfreported musculoskeletal events caused by breast cancer treatment and their effects on physical function. In total, $7.5 \%$ of patients developed postsurgical lymphedema over 2 years. Participants were asked about their ability to lift a shopping bag or suitcase in order to assess arm function; however, no relationship was detected between arm/hand swelling and upper limb function in older adults (12). Consistent with the previous studies including mixed-aged populations of breast cancer survivors, we used the DASH questionnaire to assess arm function $(3-7,10,11,13)$. It has been suggested that DASH score increases an average of 0.3 points yearly in healthy patients, and an expected normative DASH score can be calculated using the following formula: [(0.29×age of subject $)-4.46$ ] in women (14). Thus, DASH scores between 12.9 and 21.6 are considered to be in normal ranges for healthy women aged 60-90 years. In addition, the mean score for subjects who are able to do all that they want was 23.6 (15). Similarly, investigators of a previous study classified the severity of upper 
extremity disability in BRCL patients by a cutoff value of 23.7 (5). In the current study, a mean DASH score of $41.0 \pm 23.8$ indicated upper extremity disability in older patients with BCRL, and no significant correlation was determined between DASH score and age in these elderly patients.

The method of surgery and history of chemotherapy or radiotherapy are well-known risk factors for lymphedema development (2). None of the patients in the current study underwent breastconserving surgery for the treatment of their cancer; they all had mastectomy and most of them received chemotherapy and/or radiotherapy. No significant differences in DASH scores were observed when we divided patients into groups according to the surgery method and history of chemotherapy and/or radiotherapy. Likewise, Park et al. found no significant relationship between upper extremity function and history of chemotherapy or radiotherapy (4). A previous study reported that the number of comorbidities contributed to the variance in DASH scores (7); however, the presence of comorbidities did not affect upper extremity function in our study population.

Consistent with the results of Park et al. (4), we found that DASH score was not correlated with duration of lymphedema or side of lymphedema. In addition, it could be assumed that surgery performed ipsilateral to the dominant hand would cause worse disability; however, we found no significant relationship between DASH score and whether the dominant side was affected. Velloso et al. also determined no association between upper limb performance in activities of daily living and handedness in patients who underwent sentinel lymph node biopsy for breast cancer (10).

The development of chronic pain is one of the most frequent adverse events in cancer survivors (16). Forsythe et al. reported that $32.3 \%$ of breast cancer survivors had above-average pain at 10 years following completion of treatment (17). Velloso et al. observed higher proportions of pain/discomfort after nearly 2 years following surgery with $52.9 \%$ of patients having shoulder pain and $47.1 \%$ having breast scar discomfort, but the intensity of their pain/discomfort was low (10). In another prospective study, $63 \%$ of elderly women who had undergone surgery and received adjuvant chemotherapy for breast cancer experienced arm and shoulder pain at baseline (within 84 days postoperatively), $49 \%$ at 12 months, and $43 \%$ at 24 months (12). A recent meta-analysis aiming to identify risk factors for the development of pain in breast cancer survivors demonstrated that $\mathrm{BMI}>30$, education duration $<12-13$ years, lymphedema, not smoking, and history of axillary lymph node dissection, chemotherapy, hormonotherapy, and radiotherapy were significantly associated with higher odds of developing chronic pain, with lymphedema being the greatest risk factor. Conversely, the overall odds ratio for the development of chronic pain in breast cancer survivors aged $>50-55$ years was lower than in younger subjects (18). In another meta-analysis, high-quality evidence showed that development of persistent pain following surgery was associated with younger age, radiotherapy, axillary lymph node dissection, greater acute postoperative pain, and preoperative pain (19). Moreover, Smoot et al. stated that breast cancer survivors frequently have less shoulder range of motion on the affected side. The interlimb difference was greater in women with lymphedema, particularly in shoulder abduction (7). It has been noted that breast/arm pain and/or reduction of shoulder range of motion significantly interfered with arm function $(7,12)$. In our study, the percentages of patients with pain in their arm and/or surgery scar and limited shoulder motion were $16.7 \%$ and $14.3 \%$, respectively. Suprisingly, we found no significant difference in DASH scores between those with and without pain or limited shoulder motion. Moreover, in agreement with our data, Park et al. also found no relationship between arm function and shoulder pain (4). 


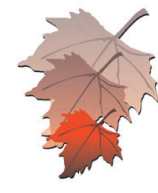

Lee et al. recently examined the potential impact of lymphedema severity on upper extremity function in 54 patients. Bioimpedence spectroscopy was performed for the diagnosis of lymphedema, and lymphedema severity was classified by ISL staging. They showed that for every 1-point increase in L-Dex score, there was a $30 \%$ increase in DASH score. But they did not determine a significant relationship between DASH and ISL staging, suggesting that ISL categories are possibly not sensitive enough to detect changes in physical function (6). In contrast, other studies indicated that neither arm volume calculated using circumferential measurements nor bioimpedance ratios contributed to the variance in DASH scores $(3,7)$. Although we found that DASH score significantly correlated with both lymphedema staging and interlimb volume difference, only volume difference was left in the regression model built to explain the variation of DASH score in older BCRL patients. Our findings are in line with those of Lee et al., who demonstrated that bioimpedance is superior to ISL classification in establishing a correlation between worse upper extremity function and increased lymphedema severity (6).

Being overweight or obese is strongly associated with increased risk of lymphedema $(2,7,9)$. However, findings regarding the effect of obesity on arm function in patients with BCRL are inconsistent. While Smoot et al. did not find a correlation between DASH score and BMI, Pinto et al. reported that obesity significantly affected DASH scores in lymphedema subjects $(5,7)$. In the current study, almost two-thirds of participants were obese, and BMI strongly correlated with DASH score, indicating that obese patients have more severe upper extremity disability. On stepwise regression analysis, BMI was found to be an independent variable significantly contributing to the variance of DASH score.

Our study has some limitations. Because it was a descriptive study, information about the cause- effect relationships or temporal sequences is limited. Moreover, performance of functional tasks is influenced by many physical, psychosocial, and environmental factors. Unfortunately, not all of these factors could be addressed in this study due to its retrospective design. Interlimb volume difference and $\mathrm{BMI}$ only explained $22.8 \%$ of the variance in DASH score, indicating that other factors aside from those variables examined in the present study also have a detrimental effect on upper extremity function in BCRL patients.

In conclusion, we found that elderly women with BRCL have upper extremity impairment, which may subsequently threaten their ability to live independently. Understanding the risk factors of upper limb disability, especially in older patients with $B C R L$, is important for delineating preventative and therapeutic interventions to help maintain their physical function over the long term. Interlimb volume difference and BMI, both of which are modifiable factors, are significantly associated with arm function in elderly patients with BCRL. Based on our results, we suggest that treatment approaches focusing on reducing not only volume of the affected limb but also BMI may be more effective for improving upper extremity function in BCRL patients. Growing evidence suggests that resistance exercises have a positive effect on arm function without increasing arm volume during or shortly after complex decongestive therapy (2022). However, the effect of weight management interventions on arm function via diet and exercise has not been established. Further research is necessary for identifying additional risk factors and evaluating the efficacy of multimodal therapy on arm function in older breast cancer survivors in particular.

\section{Acknowledgments}

We would like to thank Sevilay Karahan for her assistance in statistical analysis. 


\section{REFERENCES}

1. Cormier JN, Cromwell KD. Lymphedema, In: Zuther JE, Norton S (Eds). Lymphedema management. The comprehensive guide for practitioners. 3rd edition, Georg Thieme Verlag KG, Stuttgart, Germany 2013, pp 46-7.

2. DiSipio T, Rye S, Newman B, Hayes S. Incidence of unilateral arm lymphoedema after breast cancer: a systematic review and meta-analysis. Lancet Oncol 2013;14(6):500-15. (PMID:23540561).

3. Dawes DJ, Meterissian S, Goldberg M, Mayo NE. Impact of lymphoedema on arm function and health-related quality of life in women following breast cancer surgery. J Rehabil Med 2008;40(8):6518. (PMID:19020699).

4. ParkJE, Jang HJ, SeoKS. Quality of life upperextremity function and the effect of lymphedema treatment in breast cancer related lymphedema patients. Ann Rehabil Med 2012;36(2):240-7. (PMID:22639749).

5. Pinto M, Gimigliano F, Tatangelo $F$, et al. Upper limb function and quality of life in breast cancer related lymphedema: a cross-sectional study. Eur J Phys Rehabil Med 2013;49(5):665-73. (PMID:23698473).

6. Lee TS, Morris CM, Czerniec SA, Mangion AJ. Does lymphedema severity affect quality of life? Simple question. Challenging answers. Lymphat Res Biol 2018;16(1):85-91. (PMID:28453410).

7. Smoot B, Wong J, Cooper B, et al. Upper extremity impairments in women with or without lymphedema following breast cancer treatment. J Cancer Surviv 2010;4(2):167-78. (PMID:20373044).

8. Duger T, Yakut E, Oksuz C, et al. Reliability and validity of the Turkish version of the disabilities of the arm, shoulder and hand (DASH) questionnaire. Fizyoter Rehabil 2006;17(3):99-107. [Internet] Available from: http://dergipark.gov.tr/download/ article-file/138179. Accessed: 21.3.2018.

9. Clough-Gorr KM, Ganz PA, Silliman RA. Older breast cancer survivors: factors associated with selfreported symptoms of persistent lymphedema over 7 years of follow-up. Breast J 2010;16(2):147-55. (PMID:19968661).

10. Velloso FS, Barra AA, Dias RC. Functional performance of upper limb and quality of life after sentinel lymph node biopsy of breast cancer. Rev Bras Fisioter 2011;15(2):146-53. (PMID:21789365).

11. Hayes SC, Janda M, Cornish B, Battistutta D, Newman B. Lymphedema after breast cancer: incidence, risk factors, and effect on upper body function. J Clin Oncol 2008;26(21):3536-42. (PMID:18640935).
12. Hopkins JO, Allred J, Hurria A, et al. Lymphedema, musculoskeletal events and arm function in older patients receiving adjuvant chemotherapy for breast cancer (Alliance A171302). Breast Cancer Res Treat 2017;166(3):793-808. (PMID:28825227).

13. Lee D, Hwang JH, Chu I, Chang HJ, Shim YH, Kim $\mathrm{JH}$. Analysis of factors related to arm weakness in patients with breast cancer-related lymphedema. Support Care Cancer 2015;23(8):2297-304. (PMID:25576430).

14. Klum M, Wolf MB, Hahn P, Leclère FM, Bruckner $T$, Unglaub F. Normative data on wrist function. J Hand Surg Am 2012;37(10):2050-60. (PMID:22960029).

15. Roy JS, MacDermid JC, Woodhouse LJ. Measuring shoulder function: a systematic review of four questionnaires. Arthritis Rheum 2009:61(5):623-32. (PMID:19405008).

16. Glare PA, Davies PS, Finlay E, et al. Pain in cancer survivors. J Clin Oncol 2014;32(16)1739-47. (PMID:2479947).

17. Forsythe LP, Alfano CM, George SM, et al. Pain in long-term breast cancer survivors: the role of body mass index, physical activity, and sedentary behavior. Breast Cancer Res Treat 2013;137(2):61730. (PMID:23242613).

18. Leysen L, Beckwée D, Nijs J, et al. Risk factors of pain in breast cancer survivors: a systematic review and meta-analysis. Support Care Cancer 2017;25(12):3607-43. (PMID:28799015).

19. Wang L, Guyatt GH, Kennedy SA, et al. Predictors of persistent pain after breast cancer surgery: a systematic review and meta-analysis of observational studies. CMAJ 2016;188(14):E352-E361. (PMID:27402075).

20. Kilbreath SL, Refshauge KM, Beith JM, et al. Upper limb progressive resistance training and stretching exercises following surgery for early breast cancer: a randomized controlled trial. Breast Cancer Res Treat 2012;133(2):667-76. (PMID:22286332).

21. Do JH, Kim W, Cho YK, et al. Effects of resistance exercises and complex decongestive therapy on arm function and muscular strength in breast cancer related lymphedema. Lymphology 2015;48(4):18496. (PMID:27164764).

22. Dos Santos WDN, Gentil P, de Moraes RF, et al. Chronic effects of resistance training in breast cancer survivors. Biomed Res Int 2017;2017:8367803. (PMID:28835898). 